\title{
BENEFICENT CINEMA: STATE FORMATION, ELITE REPRODUCTION, AND SILENT FILM IN URUGUAY, 1910s-1920s*
}

\section{INTRODUCTION}

I $\mathrm{n}$ her study of early cinema and modernity in Latin America, Ana López wrote: "Latin American modernity has been a global, intertextual experience, addressing impulses and models from abroad, in which every nation and region created, and creates, its own ways of playing with and at modernity." Early Uruguayan cinema exemplifies this interaction of global phenomena with local realities and thus provides an instructive window onto some of the ways Latin Americans were "playing with and at modernity" in the early twentieth century. During that era, Uruguay emerged as Latin America's first welfare state and a model of progressive reform in the region. The complexities of that transition are reflected in socalled cine de beneficencia (beneficent cinema), film made by and for social assistance organizations for fundraising and propaganda purposes. Film historian José Carlos Álvarez identifies beneficent cinema as "something that we think was purely Uruguayan, and specific to this era." 2 While any confirmation of Uruguayan uniqueness in this regard seems premature,

\footnotetext{
* Earlier versions of this paper were presented at the Rocky Mountain Council of Latin American Studies in Santa Fe, New Mexico in March 2004, and at the Women and the Silent Screen Conference, Montreal, Canada in June 2004. Many thanks go to Ana López for editing this special volume and for all of her helpful advice and suggestions on this article. Special thanks also to Manuel Martínez Carríl, Director of Cinemateca Uruguaya, for facilitating my access to the two films discussed in this paper, and to Nancy Isenberg, who provided invaluable direction and inspiration during this project's early stages. Thanks also are owed to William Beezley and Seth Fein for helping to get this project off the ground, to José Moya for his help on the "Basque question," to Verónica Pamoukaghlián for her research assistance in Montevideo, and to Ricardo Glucksmann for sharing information on his family's history in the Río de la Plata. p. 49.

' Ana M. López, "Early Cinema and Modernity in Latin America," Cinema Journal 40:1 (Fall 2000),

2 José Carlos Álvarez, "Pervanche," in Eugenio Hintz, Historía y filmografía del cine Uruguayo (Montevideo: Cinemateca Uruguaya, 1988), p. 2.
} 
the story of early Uruguayan film is intimately tied to that of the country's state and class formation during the 1910s and 1920s. Linking early film with these larger historical trajectories are a handful of elite "ladies' committees,"ostensibly private social assistance organizations frequently subsidized by public funds. Finding themselves in need of new private fundraising venues and techniques to justify their existence and assert some autonomy vis a vis state agencies, these groups sought in film, and eventually in filmmaking, a new medium and venue for generating income and for elite reproduction and regeneration.

This article highlights the connections between social assistance, class reproduction, and early cinema in Uruguay in the 1910s and 1920s. Following a brief overview of Uruguayan welfare state formation during these years is a discussion of the origins of beneficent cinema in both the cinematic fundraisers and filmmaking experiments of elite women's charity organizations. One "ladies' committee" in particular, the Asociación La Bonne Garde, an organization that housed juvenile single mothers and oversaw their placement in "respectable" homes, was an especially important producer of early cinema. The Bonne Garde oversaw the production of a number of films, including the 1926 documentary La Bonne Garde and the 1929 feature Del Pingo al Volante, one of only three full-length silents made in Uruguay. A trite romantic tale on one level, Del Pingo reflects the anxieties of Uruguayan elites in the later 1920s, and a crisis of paternalism and reproduction that was distinctly felt within elite women's social assistance circles at that time. More generally, beneficient cinema speaks to the ways in which film, as a visual medium, played to elite audiences' narcissistic and nationalistic desires to see themselves (literally and symbolically) projected on the big screen. In that sense, these films were a modern manifestation of noblesse oblige, mediated through both modern technology and the twentieth-century welfare state.

\section{“Ladies' Committees" and State Formation in Uruguay: AN OVERVIEW}

Distinguishing features of early Uruguayan cinema can be found in the contours of the estado batllista, named for José Batlle y Ordóñez, president from 1903-1907 and 1911 to 1915 and a dominant political figure until his death in 1929. During the Batllista era, Uruguay became the first nation in Latin America to legislate the eight-hour day, the first to guarantee health care to the poor, and the home of a social security system that became a model for the rest of the continent. And in 1910, the Uruguayan Law of National Public Assistance established the notion of the right to universal 
care, declaring that "anyone . . . indigent or lacking resources has the right to free assistance at the expense of the state," legislation which set Uruguay apart from its neighbors in the Americas in the 1910s and 1920s. ${ }^{3}$

Yet despite its aspirations to social equality, Batllista policy and its evolution over time is best viewed as a modernization of paternalism, where traditional notions of social hierarchy and mutual obligation were recast and preserved in a modified, state-mediated form. As a paradigm, paternalism captures the idea of a stratified society constructed around the idea (if not always the reality) of interlocking hierarchical relationships and mutual obligation, based on relations of "protection and obedience."4 While paternalism has unequal gender relations at its root, the dominant party in the equation need not be male: elite women, for example, could be the "protectors" as well as men. In Uruguay as elsewhere, elite women had long monopolized the dispensing of charity, and thus played a vital role in the paternalistic model. Organizing and attending charitable functions and raising funds for favorite causes were an important part of elite women's lives, and a crucial venue of identity construction and social group reproduction. These fundraisers spoke directly to elite narcissism, since many attended the functions primarily to be seen in the proper places and in the right company. Beneficent activity, in other words, was at least as much about elite reproduction and self-preservation, and the justification and maintenance of social hierarchy, than it was about helping the poor. ${ }^{5}$

During the Batllista era, elite women continued to function as the main purveyors of social assistance, channeling and organizing the deployment of beneficence. What was different was that by the 1910 s they were doing this social mothering with substantial public sponsorship and government oversight. Like other similar state-building projects in Europe and elsewhere, the estado Batllista was a "hybrid" state which encompassed a large "parapolit-

3 Asistencia Pública Nacional, Publicación oficial de la dirección general (Montevideo, 1913), p. 7.

${ }^{4}$ Gerda Lerner defines paternalism as "the relationship of a dominant group-considered superiorto a subordinate group-considered inferior-in which the dominance is mitigated by mutual obligations and reciprocal rights." This conceptualization is echoed in Sandra Lauderdale Graham's study of masters and servants in nineteenth century Brazil, where she describes relationships based on unequal interactions of "protection and obedience," relations not limited to master/servant interaction, but diffused throughout Brazilian society. See Gerda Lerner, The Creation of Patriarchy (New York: Oxford University Press, 1986), p. 239, and Sandra Lauderdale Graham, House and Street: The Domestic World of Servants and Masters in Nineteenth-Century Rio de Janeiro (Austin: University of Texas Press, 1988).

5 For more on Batllismo and paternalism, see Christine Ehrick, "To Serve the Nation: Juvenile Mothers, Paternalism and State Formation in Uruguay, 1910-1930," Social Science History 29: 3 (Fall 2005), pp. 489-518. 
ical sphere" of private and Church institutions under effective state control. ${ }^{6}$ The state turned to private initiative to fill in gaps in care, encouraging the formation of secular (or quasi-secular) comités de damas (ladies' committees) to help with social assistance efforts and create a bridge between public assistance and private philanthropy. A number of important elite women's social assistance organizations emerged between the years 1910 and 1915 in response to this new climate, most of them targeting poor mothers and disadvantaged children. One such organization was the Asociación La Bonne Garde, founded in 1911 to assist unmarried pregnant juveniles whose families or guardians could not afford (or were unwilling) to take care of them during their pregnancy and early stages of motherhood. In stark contrast to these young wards, the women heading up the Bonne Garde were from the most distinguished and recognized families in Montevideo, including the female relatives of leading politicians, jurists, physicians, and landowners: Thus the traditional paternalistic relationship-between the impoverished, dependent, and obedient charity-recipient and the wealthy, powerful, and protective charity-giver-was preserved in the Bonne Garde.

Like other similar organizations, the Bonne Garde began as a private endeavor, but within a few years it was brought into the state's orbit. During the 1920s the Bonne Garde and groups like it became increasingly dependent on government subsidies as private support for their work began to dry up. Public funds allowed such groups to expand their operations, but it also curbed their autonomy. This shift also threatened the very position of elite women in social assistance, whose presence was justified and sustained by their supposed ability to channel private funds into public assistance projects. As the percentage of private funds in these organizations' budgets shrank, the raison d'être for elite women in social assistance declined accordingly. By the early 1920s both bureaucrats and legislators sought to secure greater government oversight of the daily operations and expenditures of these organizations, and many pushed to replace elite damas with government-trained (middle class) social workers.

Preserving the primacy of private charity was thus key to shoring up traditional notions of paternalism and the social standing of these ladies' committees, who in turn often linked elite charitability to the maintenance of class privilege and the moral health of the dominant classes. Beneficent cinema has its origins in this elite feminine parapolitical sphere, which became increas-

\footnotetext{
${ }^{6}$ In this Batllista Uruguay resembles the French welfare state of the Third Republic. See, for example, Janet R. Horne, A Social Laboratory for Modern France: The Musée Social and the Rise of the Welfare State (Durham, NC: Duke University Press, 2002).
} 
ingly linked to and dependent upon the Uruguayan state at the same time that it sought modern means of raising funds and reproducing itself within the private realm. All of this, I argue, underlies the foray of some of these ladies' committees into film and film production. Charitable groups had long staged theatrical, musical and other productions as fundraising events. Some of these damas saw in film technology new avenues for fundraising and propaganda in the private sphere, and they sought to use the cinema to raise money and buttress traditional values of elite privilege and obligation.

\section{EARLY BIOGRAPHS AND FUNDRAISERS: THE ORIGINS OF BENEFICENT CinEMA}

Studies of gender and early cinema in the United States have shown that, by the 1910 s, the movie industry was encouraging greater (middle class) female attendance at movie houses as a way to improve the cinema's reputation and make going to the movies seem more respectable. ${ }^{7}$ By and large, cinema in Latin America attracted a more elite audience earlier on than in the United States, which also suggests that it was more acceptable for women to go to the movies, a key ingredient in the development of beneficent cinema. ${ }^{8}$ Nevertheless, it seems clear that cinema owners in Uruguay, like the United States, sought a seal of approval by creating close ties with the gente bien. In the 1910 s, therefore, a relationship of mutual convenience developedbetween ladies' committees seeking new fundraising venues and moviehouse owners wanting an air of respectability. Initially, social assistance groups began using theaters and moviehouses to host non-cinematic fundraisers. As early as 1915, for example, the group Entre Nous was using the Cine Dore to host public speakers, dance performances, and other charity events. ${ }^{9}$ But just as many old stage theaters evolved into movie houses, some ladies' committees began exhibiting films as a way to raise private funds.

\footnotetext{
7 Shelley Stamp, Movie-Struck Girls: Women and Motion Picture Culture after the Nickelodeon (Princeton, NJ: Princeton University Press, 2000), pp. 5-6.

${ }^{8}$ See, for example, Guillermo Caneto et al, "Historia del cine mudo en la Argentina, 1896-1933," in Fundación del cine latinoaméricano, ed., Cine Latinoaméricano (I896-1930) (Caracas, Venezuela: Consejo Nacional de la Cultura, 1992). Here, the authors describe similar patterns of elite patronage of and participation in early Argentine cinema to that observed in the Uruguayan case. In an article on early Cuban cinema in the same volume, the authors observe that "for the bourgeoisie and professional classes . . c cinema became a location for social and family encounters" (See Héctor García Mesa et al "El cine mudo en Cuba, 1897-1933," in Fundación del cine latinoaméricano, Cine Latinoaméricano, p. 148). This same article also mentions that in Cuba, in contrast to the elite film fundraisers documented in places like Uruguay and Argentina, labor unions held similar events to raise money for strikers. All of this raises intriguing questions about the comparative class politics of early cinema, a theme that lies beyond the scope of the present project.

9 "Notas sociales: Entre Nous," Página Blanca (15 July 1915), p. 55.
} 
In April 1918, the Montevideo newspaper El Día announced the beginning of a new series at the Cine Rex. These so-called "miércoles blancos" (white Wednesdays) were days when a portion of proceeds from the films exhibited went to benefit the organization Entre Nous. ${ }^{10}$ As with most society events, newspaper reports on those fundraisers listed the names of the organizers and/or those in attendance, helping to create the image that that these cinematic spectacles were the place to be for Montevidean high society. In September of 1919, El Día reported that "these Wednesday meetings at the Cine Rex are an obligatory stop for our society." was competing with a charity-oriented Wednesday matinee of its own, and the Cine Trianon was holding regular social assistance events on Fridays. ${ }^{12}$ By this point, many varied ladies' organizations (except for the conservative Catholics, who were by and large more suspicious of the film medium), were organizing film fundraisers on a fairly regular basis. ${ }^{13}$ The fact that these events were often matinees suggests they were tailored specifically to a feminine audience.

Towards the end of 1919, we see the first reports that these ladies' committees were making themselves the subject of locally made films, an important step in the development of cine de beneficencia. Guillermo Zapiola explains the origins of this film genre in the following terms: "The organization needed resources from society people and from here the idea emerged to make films in which these people would act, raising money through the film's subsequent exhibition." ${ }^{14}$ In September 1919, the Trianon reported projecting a film featuring "well-known ladies with their children." 15 The first true example of beneficent cinema in Uruguay, it seems, was Pervanche ["periwinkle" in French], made sometime in 1919-1920. Some histories attribute this film to the Bonne Garde, others to the Entre Nous. The (scant) existing historical evidence points the latter. In November 1919, El Día reported: "Currently the girls of Entre Nous are working on 'filming' an interesting comedy in which a select group of 'the girls' and a number of gentlemen will perform." " Very little is known about Pervanche except that it was report-

10 "De Entre Nous," El Día (25 April 1918), p. 6.

11 "Entre Nous," El Día (17 September 1919), p. 7. See also "Entre Nous," El Día (10 September 1919), p. 6.

12 "De Beneficencia," El Día (9 June 1919), p. 6; "Entre Nous," El Día (10 September 1919), p. 6.

${ }_{13}$ Rather than engage in film screening and production, the conservative Catholic Ladies' League entered into radio broadcasting in the late 1920 s as a means to spread "the good word" and recruit for their organization.

14 Guillermo Zapiola, "El cine mudo en Uruguay," Fundación del cine latinoaméricano, Cine Latinoaméricano, p. 327.

15 "De Beneficencia," El Día (26 September 1919), p. 7.

16 "Entre Nous," El Día (6 November 1919), p. 6. 
edly lost forever in 1925 when the husband of the lead actress burned all surviving copies to spare himself the shame of having a wife who had appeared in a movie. Thus while exhibiting films for a high society audience may have been acceptable by 1920, actual performance in one (especially for married women) was, apparently, still a matter of some controversy.

While Entre Nous may have pioneered beneficent cinema in Uruguay, it was the Bonne Garde that really developed it. Another mystery film in this category is the 1927 Aventuras de una niña parisien en Montevideo [Adventures of a Parisian girl in Montevideo]. Yet another example of the Francophilia of the ladies' committees, this film was also lost, and very little is currently known about it. Cinemateca Uruguaya believes it was probably but not necessarily made to benefit the Bonne Garde. There are two surviving (or partially surviving) films that we can unequivocally attribute to the Bonne Garde, however: a self-titled documentary made in 1926 and the fulllength 1929 feature Del Pingo al Volante. Only a few minutes of La Bonne Garde are presently available due to the film's unrestored condition. But what we do have offers an insightful look into the visual self-representation (and self-promotion) of ladies' committees via their charges. Not surprisingly, the goal of the documentary was to present a sanitized, happy, and healthy environment where grateful young women were taught to become loving, capable, and responsible mothers. What is missing in the film's depiction (or at least in the available fragments) are servitude, coercion, and the presence of the state.

La Bonne Garde opens with an anonymous woman hurrying down a desolate city sidewalk, unescorted and clearly in a desperate state. In her arms is a child, bundled in a blanket. The scene readily communicates the woman's shame, vulnerability, and need for "paternalistic" protection. It also represents her as a caring mother, risking her own honor rather than abandoning her child. The woman then arrives at and knocks on an unmarked door; the fact that she herself is seeking assistance is underlined by a long shot of her hand on the door. The intertitles tell us "llamád y os abrirán" [call and they will let you in]. The door opens and a middle-aged woman in a habit-like costume invites the young woman inside. It is thus a paternalistic scene, where the vulnerable and the powerless ask for help and are offered shelter and protection by the benevolent hand of privileged women. But the scene is also a deceptive one, presenting an idealized version of private paternalism. The State is something of an invisible player here; the emphasis is on individual charity and the Church-like sanctuary nature of the Association, not of the Bonne Garde as a wing of the state Juvenile protection/detention infrastructure. 
Once inside the Bonne Garde itself, we find a scene of community and warmth, the opposite of the coldness and shame of the street. An opening shot of the interior patio shows us a group of young women in light-colored uniforms, some toting small children, others visibly pregnant. The film then cuts to an idyllic view of the young mothers in the kitchen, happily baking cookies for their children in what the intertitles tell us is a cooking class. The hand imagery of the film's opening scene continues, with long close-ups of hands in the various stages of preparing cookies (mixing, rolling, cutting). It is a scene of labor, but one with an element of leisure to it, since the women are learning to cook by preparing treats for themselves and their children. In the next scenes we see the children happily enjoying the fruits of their mother's labor, in an atmosphere which suggests a healthy and abundant home. The children look content and well-fed, and the camera pauses on an especially chubby toddler grasping a newly-made galletita.

Yet despite this on-screen representation, the Bonne Garde was at least as much a detention facility as it was a refuge, and we do not see any of the coercion that was very much a part of the Bonne Garde's relationship with its official wards. While some women did arrive at the Bonne Garde in the manner depicted in the documentary, many more were wards of the state transferred in late pregnancy from other juvenile facilities and held at the Bonne Garde involuntarily. Running away from the Bonne Garde or the placement homes could mean an arrest warrant and incarceration, and the historical record reveals protests by wards of poor treatment and plots of violence against staff. ${ }^{17}$ The film also shows us a scene of domestic labor completely devoid of the drudgery and exploitation that was the lot of many of these young women. Bonne Garde clients were often farmed out (with or without their children) to work as low-paid domestics in the homes of mostly middle class families where, supposedly, they were to receive both occupational training and moral guidance.

Not only did the Bonne Garde have an interest in portrayi their facilities as caring, loving sanctuaries; they also needed to present ounne Garde wards as sympathetic victims, as opposed to criminals or moral degenerates. The film has several long posed shots of Bonne Garde wards-introduced with the intertitle "A representative group of protected mothers"both in group shots and in scenes of individual mothers holding their children. While blond and light-eyed children seem to attract more of the

\footnotetext{
${ }_{17}$ Consejo Patronato de Delincuentes y Menores, 1927 Folder 88, 1-5. Archivo General de la Nación, Montevideo, Uruguay.
} 
camera's attention, the mothers reflect the profile of Bonne Garde clients, who were by and large a combination of whites and mestizas. At this point the audience is asked "How can we blame these innocents?," leaving it conveniently vague as to whether the question refers to the infants, their mothers, or both. This invites the viewer to sympathize with the young mothers, but the question as to who might be responsible for their situation (i.e. pregnancy, poverty, and abandonment) was left unanswered. For obvious reasons, the film could not portray wards in the same way as they were all too often represented in official documents, where Bonne Garde leaders frequently criticized them as morally degenerate, overly sexual, lazy, and dis,respectful. In public fundraising venues, it was imperative to present the beneficiaries of charity as helpless, innocent, and grateful for the assistance of the more fortunate, in keeping with the paternalistic fantasy of the dominant classes.

\section{Del Pingo al Volante and the Importance of 'Good Breeding': NARCISSISM AND NATIONALISM}

The paternalistic fantasy plays out in a different way in the Bonne Garde's most important film project. While the 1926 documentary was apparently made with the specific aim of soliciting funds for the Bonne Garde, the 1929 film Del Pingo al Volante was a more ambitious undertaking. The film's title, which literally translates as "From the Racehorse to the Automobile," announces that the story is about changing times and city/countryside relations, but it also engages themes of masculinity, nation, and the reproduction of the elite classes. Overall, Del Pingo exemplifies the characteristics of beneficent cinema and the ideological framework of ladies' committees like the Bonne Garde in the late 1920s. Unlike the 1926 documentary, in Del Pingo the urban poor are nowhere to be seen. The wealthy were perhaps more interested in looking at themselves on the screen than they were at the social unfortunates who were meant to benefit from their largesse.

Del Pingo al Volante was filmed between May and July 1929 as part of a big fundraising push by the Bonne Garde. The film was hastily made, with rather basic production values for the time - the filmmakers used only a single and mostly stationary camera, and the movie is crudely edited in a number of spots. Yet in the weeks leading up to the film's August premiere, the society page of El Día-a Batllista newspaper and the main Uruguayan paper of record for this era- bubbled over with excitement about the project, calling it "one of the great events of the year," and proclaiming-with some exaggeration - that Del Pingo represented the beginning of a "national cine- 
matographic industry" in Uruguay. ${ }^{18}$ The film's screenplay was written by Antonio Soto (who wrote under the pseudonym "Boy"), a moderately successful author of unremarkable romantic novels, often set among high society. ${ }^{19}$ The director was Roberto Kouri, a man who remains a bit of a mystery. According to Zapiola, Kouri was a "Lebanese who got off a boat in the port of Montevideo in 1928, said he knew how to make movies . . finished his work ... and disappeared into thin air." "There is no evidence," Zapiola continues, "that he had made a film before or after this . . in Uruguay or anywhere else." ${ }^{20}$ El Día reports from 1929 tell a very different story, however, describing Kouri as a "perfect artist for this kind of work who with this Bonne Garde film has lived up to the reputation he enjoys in countries like France, the United States and Germany as a great director." ${ }^{21}$ It seems likely that the reality lay somewhere in between: while there is little evidence that Kouri was considered a "great director" in Europe or the United States, it seems unlikely that Del Pingo was, in fact, Kouri's first and only film. In May 1929 El Día reported that the Bonne Garde had invited Kouri from Buenos Aires to make the film, suggesting that he was at least involved in film making in Argentina prior to being hired for the Bonne Garde project.

Del Pingo's credits list "Max Glucksmann Uruguay" as the studio where the film was put together. The movie industry in Montevideo was dominated by this Buenos Aires-based family, which was headed by its patriarch, Max Glucksmann, an Austrian immigrant. Through Max's many brothers, the Glucksmann name came to be synonymous with modern entertainment in the Río de la Plata and beyond (cinema, radio, phonographs, etc.). Younger brother Bernardo, whom El Día described as a "well-known businessman" and who had close ties to the Montevidean elite, managed the Glucksmann family affairs in Uruguay. Significantly, in the 1920s Bernardo Glucksmann served on the Board of the Uruguayan Auto Club, a position he held with several well-known, aristocratic and politically powerful men, indicative of the social position of the Glucksmann family in Montevideo and to the links between cinema and social elites during this era. ${ }^{22}$ Lastly, Del Pingo premiered at the Cine Rex, a prominent luxury moviehouse owned by the

\footnotetext{
18 "Del 'Film' de Beneficencia," El Día (11 July 1929), p. 11, "El film de la Bonne Garde," El Día (03 August 1929), p. 12.

19 See for example, Antonio ('Boy') Soto, Marú: novela romántica desarrollada en cartas (Buenos Aires: M. Gleizer, 1927).

${ }^{20}$ Zapiola, "El cine mudo en Uruguay," in Cine Latinoaméricano, p. 327

21 "El film de la Bonne Garde," El Día (03 August 1929), p. 12.

22 "El Señor Bernardo Max Glucksmann," El Día (7 April 1928), p. 7
} 
Glucksmann enterprise, which also meant that the Bonne Garde could count on the powerful Glucksmann promotion machine to publicize their film.

Del Pingo's premiere was a major society event, and tickets sold out quickly. El Día published the text of the special invitation to the screening, signed by "members of the Commission," which included the Uruguayan President's wife and daughter along with many of the most important, aristocratic last names in Montevideo. Honored invitees to the premiere included (not surprisingly) President Campestiguy himself, as well as the Directors of both the National Public Assistance and the Council for the Protection of ,Delinquents and Minors, the state agencies overseeing the care of juveniles under state custodianship and the main bodies overseeing the Bonne Garde and its public budget. The invitation to these last two men was significant, for it suggests that the Bonne Garde dearly wanted to demonstrate its efforts (and its success) in attracting elite interest and funds for its project.

As with other examples of beneficent cinema, many of the actors in Del Pingo were men and women from Montevidean high society. Zapiola in fact described the film as an "involuntary documentary of the era," due in part to the fact that Montevidean elites in this film were essentially playing themselves. ${ }^{23}$ El Día's society page constantly reminded its readers about the "well-known" young men and women of "society" who acted in the film. The notary in the film's opening segment, for example, was played by a Señor Saralegui, undoubtedly Pedro José Saralegui, who was both a "notary public and a musical composer." 24 The female lead (Susana) was played by Luisita Ramírez García Morales and her mother (Señora de Aguiar) by a Señora de García Morales. The two were probably related (aunt and niece perhaps?) and Luisita may have been the daughter of Juan Andrés Ramírez, a powerful political figure and leading member of the local aristocracy. The actors who played the two men vying for Susana's heart were Luis Alberto Hill Hamilton and Carlos Vanrell Ramos, both the sons of well-to-do families living in the Old City. Hill Hamilton, for one, had previous acting experience and had participated in earlier theatrical productions staged for beneficent ends. ${ }^{25}$ Reports on the film also listed the names of the aristocratic families whose urban mansions and rural estates were used as sets, along with other locales-such as the Parque Hotel and Casino and the Punta Car-

\footnotetext{
${ }^{23}$ Zapiola, "El cine mudo," p. 327. We are introduced to some of the cast members in the intertitles, others are provided elsewhere.

${ }^{24}$ Arturo Scarone, Uruguayos Contemporáneos (Montevideo: Barreiro y Ramos, 1937), p. 454. Whether Saralegui wrote any music for the film is unknown.

${ }^{25}$ See, for example, El Día's Theater Column; 30 April 1928 p. 9 and 4 May 1928, p. 8.
} 
retas Golf Club-which would have been familiar ground for Montevideo's rich. And in several scenes of the film-most notably a children's ballet class taught by "Miss Harvey" and a party held at a luxurious mansionlong pauses and clear facial shots give the audience a good look at the film's extras. Del Pingo's audience was clearly supposed to recognize many of the people who appear in these scenes. In an era when the Hollywood film industry was becoming increasingly global, this was clearly an exercise in local film making aimed at a specific audience.

What we also have here is a narcissistic (and voyeuristic) venture in which elites paid for the privilege of watching themselves (and their peers) on the big screen. Private charity had long played to that narcissism: the gente bien attended fundraisers and gave to charitable causes in part because of their desire to be seen in all the right places and to conform to a certain image. Women's charity, a key component of elite reproduction, thus had a strong element of visuality to it, and film technology was easily adapted to serve its purposes. By putting some of those elites in the films themselves, beneficent cinema took that process one step further, adding another dimension to the desire to be seen, and underscoring the fact that paternalism and narcissism were, in essence, two sides of the same coin. While Del Pingo appears to have been a smashing success, at least among Uruguayan high society, it is unclear how much money the film actually made or whether it accomplished much in terms of securing the Bonne Garde's position. That no other films were forthcoming, even though Del Pingo was set to be the first of a number of similar cinematic projects, suggests that the project did not turn out as well as planned. But one must also consider the fact that this film was made and released only a matter of months before the onset of the Great Depression (and at the end of the silent era), which may have combined to derail ambitions for future projects.

Del Pingo al Volante is most obviously a film about modernity and masculinity, but it is also a film about breeding and the reproduction of elites. Viewed through the lens of paternalism, what we really find is a discourse about elite responsibility and obligation, a call for a renewal (and/or survival) of older forms of paternalism within a modern framework, and anxieties about the future position of elites in late Batllista Uruguayan society. This film is also very much about the position and politics of groups like the Bonne Garde in the shifting sands of Uruguayan class and state formation in the late 1920s.

To briefly summarize Del Pingo's plot: At the film's opening we meet a widow from a wealthy Montevideo family as she learns that her inheritance 
(from her deceased husband) is about to be transferred to her sister-in-law. The only way to maintain her economic position (i.e. access to her husband's family's wealth) is to for her daughter to marry her nephew (the daughter's first cousin), the son of the sister set to inherit the family assets. The sister-in-law, her son, and daughter are then invited to spend some time in Montevideo, where the two cousins meet (they themselves are ignorant as to the financial angle behind this encounter). The country cousin finds himself in competition with a slick urban dandy but, despite some fumbles by the country cousin and the dandy's dirty tricks, the two cousins fall in love, saving the family fortune and saving the daughter from marrying her , morally inferior urban suitor.

Since beneficent cinema was about elite reproduction in symbolic social way, it is only fitting that one of its premier examples should deal with elite reproduction on a more biological, literal level. The family at the film's opening (Susana de Aguiar and her mother) find themselves in crisis, facing complete ruin. Metaphorically, this can be read as the crisis of Uruguayan elites generally, facing economic but also moral ruin if they cannot adapt to the challenges of the current circumstances (i.e. modernity). This is a family (and, by extension, an elite class) in need of a patriarch and a moral compass. What is called for, in the film's vision, is an infusion of health, morality, and virility from the countryside. That infusion comes in the person of Juan Alberto Madariaga, the creole estanciero hero. But before we meet the hero, the audience meets his rival: Eduardo Santos, the urban dandy. It is noteworthy that the term "vástago" (offspring) is used in introducing both men, reinforcing the film's focus on breeding, blood, and inheritance (financial, biological, and social/cultural). In this case, both men have been bequeathed large amounts of wealth, but do not possess equal moral portfolios. Much of this is attributed to Eduardo's overcivilized urban upbringing, in contrast to Juan Alberto's healthful life on a rural estate.

The son of a well-to-do family, Eduardo Santos is a playboy who drinks too much, plays around with too many women, and is generally is lazy, dishonest, and irresponsible. We are first introduced to him when a friend goes to his house, late in the day, to find Eduardo still asleep, obviously hung over from the night before. Inside the mansion, we encounter a scene of wealth and moral dissolution. The camera first focuses on an elegant statue with an item of clothing draped across one arm, then moves down towards the floor, revealing an expensive-looking oriental rug and more clothing strewn across the floor. The friend then enters Eduardo's bedroom, only to find him asleep backwards in bed, still in his tuxedo and with his shoes on the pillow. The friend later chastises Eduardo for his drunken behavior the night before, 
something which has already been communicated visually by the bedroom scene. Throughout the film, Eduardo seems to spend his days hedonistically indulging in his own pleasures and manipulating others to serve his needs and whims. Wealth and the comforts of city life, in other words, have rendered Eduardo a social parasite with no sense of obligation, responsibility, or honor. In her study of the perceived crisis of Victorian manhood in United States at the turn of the twentieth century, Gail Bederman writes of the "widespread belief that excessive civilization was threatening young American men with weakness and neurasthenic breakdown" ${ }^{26}$ We can easily see Eduardo Santos representing this malady, where the luxuries and excess comforts of civilization have rendered him dishonorable and self-indulgent: in other words, not fully manly.

Juan Alberto, in contrast, is the embodiment of the idealized male. Not only his gender, but also his class and (as we will see below) his ancestry all combine to shape this manly symbol of the nation and its best hope for the future. Juan Alberto is not just any rural male, but a wealthy estanciero. He is also a wise and honorable patriarch, both physically and morally fit: the mirror image of Eduardo Santos. The contrast between Eduardo and Juan Alberto, and between city and countryside, is visually communicated in a dramatic way. Before our hero makes his appearance, several long panoramic shots of the countryside and of cows and sheep being herded by sturdy gauchos on horseback testify to the health and abundance of the Uruguayan interior. A shot of a large rural estate, foregrounded by grass waving in the wind, parallels an earlier shot of the urban Santos mansion, fore grounded by automobiles ["volantes"] speeding by on the avenue.

After this naturalistic (and nationalistic) introduction, our hero appears on horseback ["pingo"] and wearing a poncho, the latter serving both to distinguish him as the master of the estate and to underscore his proximity to the gauchos under his protection. In contrast to the hungover Eduardo, we see our hero "building his muscles in athletics," as well as "sharing the rustic rural life with his brava peonada." The audience sees Juan Alberto participating in breaking a horse and struggling with a particularly recalcitrant cow. We also see the hero drinking yerba mate and enjoying an asado with "his" gauchos, reinforcing his construction as a nationalist symbol, and an embodiment of idealized paternalism. The light and expansive feeling of these outdoor rural scenes stands in stark contrast to the suffocating luxury and lassitude of Eduardo's bedroom.

\footnotetext{
${ }^{26}$ Gail Bederman, Manliness and Civilization: A Cultural History of Gender and Race in the United States, 1880-1917 (Chicago: University of Chicago Press, 1995), pp. 78-88.
} 
Juan Alberto's healthier, more masculine, upbringing is not the only reason for his superior human quality, however. At several points, Del Pingo emphasizes the importance of good blood in shaping character, thus reinforcing views about breeding and natural class superiority that were a keystone of the elite outlook. We are told via intertitles that our protagonistJuan Alberto Madariaga- is of Basque descent. According to José Moya, this choice was in keeping with both the realities and perceptions of Basque immigrants in the Río de la Plata at the time. Moya has noted that: "Basques enjoyed the highest reputation among all the Iberian ethnic groups in Argentina." More so than other immigrant groups, Basques were more likely to have settled in rural areas, where they were well represented among the elite classes, a socio-economic position which was often attributed to the "presumed racial superiority of this legendary race of iron and conquistadors." More to the point, Moya also highlights the ways in which Basques (and Basque blood) were romanticized as representing the values of a more idyllic traditional society. ${ }^{27}$ Combined with his rural upbringing, our protagonist's superior blood thus makes him the idealized male: civilized yet still virile and honorable. ${ }^{28}$

This auspicious biological inheritance will allow Juan Alberto (and his sister Amelita) to adapt easily to the refinements of city life upon their arrival in Montevideo. The hero's initial adjustment to the Uruguayan capital shows his awkwardness in this new environment, and provides some opportunities for comic relief. We see him getting stuck in a revolving door, and clumsily stepping on his partner's toes when receiving dancing lessons, for example. Many of these missteps provoke the laughter of young women, whose ridicule challenges and undermines our hero's prowess in this new environment. But not every new thing is difficult for our hero; we are reminded of his skills and virility when we see him easily make a hole in one on the golf course (a none-too-subtle sexual allusion). Juan Alberto's sister Amelita, in the meantime, shows up in the city with a trunkful of out-of-date fashion (an equivalent faux pas apparently), to the great amusement of her city cousins. This latter point also communicates to the elite female audience of this film, who would be enough in tune with the subtleties of fashion trends to understand the joke. But the siblings' inherent superiority of blood allows them to adapt quickly and easily to civilization. When the intertiles reassure the audience that "good ancestry never fails us," Del Pingo is speaking directly to the

\footnotetext{
27 José C. Moya, Cousins and Strangers: Spanish Immigrants in Buenos Aires, 1850-1930 (Berkeley: University of California Press; 1998), pp. 232-234.

${ }^{28}$ See Bederman's analysis of Tarzan in Manliness and Civilization, pp. 218-232 for more on the idealization of the combination of "superior" blood and "savage" upbringing.
} 
elite audience for whom the film was principally made. Culture and good upbringing were necessary, but good breeding and pedigree was the ultimate guarantor of success and supremacy. Juan Alberto's combination of pastoral manliness and "good ancestry" ultimately serves him well in his pursuit of Susana de Aguiar, with whom he is instantly enamored.

The city does provide some needed refinement for these "pajueranos."29 Juan Alberto does learn to dance, and to drive a car, for example. But, for the most part, our hero is not changed by the city; he moralizes it by his presence. Juan Alberto's impact on city life is best represented in his winning the heart of Susana de Aguiar. While Amelita's transformation is largely superficial—she learns to dress better and more fashionably-Susana's is more profound. Midway through the film, there is a birthday party for Susana, to which both her suitors are invited. Juan Alberto gives her a rather simple doll as a present, while Eduardo gives her expensive-looking jewelry. Susana initially ignores the doll, leaving it and our hero behind in favor of Eduardo and his jewels. Later, towards the end of the film, when she has learned the truth about Eduardo's dishonesty and immorality, we see Susana looking lovingly at the doll, which she then strokes and holds in her lap as if it were a child. Initially a sign of Juan Alberto's innocence and naiveté, the doll also puts Susana prescriptively in the role of a potential mother. Her newfound love for the doll not only notifies the audience of her love for the hero, but symbolizes her move away from superficial baubles and her willingness to submit to Juan Alberto and destined motherhood. Del Pingo is interested in breeding and elite reproduction, so childbearing is an important (albeit understated) element here. We learn from Señora de Aguiar at the beginning of the film that Susana "is a very difficult girl," meaning she is not easily controlled. ${ }^{30}$ Yet by the end, Susana is broken by Juan Alberto, in much same way we had earlier seen him breaking a horse on his estancia, and she is now ready to be a healthy and moral wife and mother. By this consummation, the family fortune is secured, as is the regeneration and reproduction of the elite.

In keeping with the film's title, allusions to livestock and breeding are intermingled with the importance of the automobile as a symbol of modernity, a key aspect of the nationalist vision conveyed in Del Pingo. It was imperative for

\footnotetext{
29 This term, used throughout the film to refer to Juan Alberto and his sister, is another example of the local slang used in Del Pingo. The term literally refers to those who come "para afuera" (from the interior), rendered in the "hick" pronunciation of the Rio Platense countryside.

${ }^{30}$ Overcivilized femininity, Bederman explains, manifested itself in women's ignoring their maternal duties and "drained their capacity to be healthy mothers." Bederman, Manliness and Civilization, p. 87 .
} 
elites like Juan Alberto to take the reins of modern technology (and, by extension, the nation) in order to direct it in a healthy and productive fashion. In other words, it was important that someone with a foot in the tradition of the "pingo" be at the literal and symbolic wheel of the "volante," in order to steer the nation on its proper course. We have earlier noted Bernardo Glucksmann's position on the board of the Uruguayan Auto Club, testimony to the links between cinema, automobiles, modernity, and elite status during the 1920s. A further link in this chain is found in the Bonne Garde itself, which, in addition to being a promoter of cinema, also played a role in the history of the automobile in Uruguay. In 1922, in an earlier fundraising spectacle, the Bonne Garde sponsored an automobile race on Carrasco Beach, an event that automobile historian Álvaro Casal Tatlock noted was the "fourth auto speed race in the Río de la Plata." 31 Similarly, Del Pingo's climactic scene is an automobile race between the two male rivals along that same stretch of shoreline, which in a way recreates the earlier race. What we have, in other words, is an overlapping three-way linking between early cinema, automobiles, and the ladies' committees, underscoring, among other things, the ways in which an elite women's group like the Bonne Garde actively sought to harness itself to two of the most potent symbols of modernity in an effort to preserve its own-increasingly anachronistic-place in Uruguayan society.

The auto race is the film's most dramatic and only action scene, clearly shot from the back of a third vehicle running ahead of the other two. One also notes that Juan Alberto is driving a left-hand drive car while Eduardo is in a right-hand drive car. This was another aspect of technological transition in 1920s Uruguay; the country was changing over from British style righthand drive (and driving on the left side of the road) to American/French style of left hand drive cars and driving on the right side of the road. According to Casal Tatlock, this transition from the British to the U.S. style began during the First World War, when European imports were hard to come by, and more and more automobiles were being imported from the United States. ${ }^{32}$ Did the filmmakers intend to hitch our hero Juan Alberto to the "American" style of savage manhood (and by extension the symbols of American frontier nationalism), while associating Eduardo with a European effeminate and degenerated masculinity? In the meantime, Susana de Aguiar participates in the race only as Eduardo's passenger, representing the largely passive role the feminine is meant to play in this battle for control over the nation's future.

31 Álvaro Casal Tatlock, El autómovil en el Uruguay: Los años heroicos, 1900-1930 (Montevideo: Ediciones de la Banda Oriental, 1981), p. 58.

32 Tatlock, El autómovil, pp. 42-43. 
The gender politics of this film are more complex than a simple active male/passive female dyad, however. It is important to note, for one, that there are no fathers in this film, and mothers are the family patriarchs. Both Susana and Juan Alberto's mothers are widows, and we never meet Eduardo's family. As widows, these women are allowed to assume leading roles as protectors of the family and advisors to their children without usurping traditional male privilege. This way, the Aguiar family fortune could be threatened without impugning the family's male head, and surely Susana's marriage would have been arranged differently if her father (or an older brother) were around. But this device also speaks to the position and responsibility of elite mothers for preserving lineage. It is Susana's mother, after all, in collusion with her accountant, who starts this whole story in motion. ${ }^{33}$ Mothers are the caretakers of the family, entrusted with assuring good matches for their children and preserving the family fortune. Women (especially widows) are also allowed to work behind the scenes, securing their family's future without asserting themselves directly or publicly (i.e. in an overly masculine way). In the film, the older women function as interested observers, who from the sidelines-usually a sumptuous sofa-are witness to the drama between Susana and her two suitors. Juan Alberto's mother in particular offers her son comfort and advice at crucial moments. This is an interesting device, given that the film was made to benefit an organization run by women much like Señora de Aguiar and her cuñada. Social assistance activity, after all, allowed elite women to play leading roles in an acceptable arena, thus helping to secure class reproduction and privilege without overtly challenging gender privilege. In many ways the shadow roles of the elite widows in this film echoes the inconspicuous yet pivotal place of the ladies' committees in class relations (and state formation).

What we have, in other words, is a vision of national salvation in which elites—but especially elite women—are pulling the strings behind the scenes, pointing their children in the proper direction. For this story, lastly, is also one of nationalist politics and the role ladies' committees played in deploying and wielding those discourses. By the late 1920s, elite women were weaving themselves into the nationalist project, in preparation for what was by then inevitable women's suffrage, and in defense of the nation through the preservation of elite prerogative. By this time, for example, the conservative Catholic Ladies' League was declaring itself the "defender of the borders." ${ }^{34}$

\footnotetext{
${ }^{33}$ It is significant that there is no moral judgment at all passed on the mother for this act of manipulation-nor is there ever any issue made of the fact that the two lovers are first cousins.

34 "Importante Aviso," El Eco de la Liga de Damas Católicas del Uruguay 263 (August 1931), p.
} 3261 . 
By holding up Juan Alberto as the symbol of the nation, Del Pingo also conforms to the rising tide of creole nationalism enveloping Latin America at this time. The film's opening scene shows Montevideo's Old City, shot from the Cerro district with a grassy hill and a grazing horse in the foreground. Visible in the scene is the architecturally distinct and easily recognizable Palacio Salvo. This twenty-six story building was the tallest in South America when it was completed in 1927, and was thus a point of pride for Uruguayans. In its composition, this brief scene accomplishes a great deal, introducing the film's thematic emphasis on modernity and urban/rural issues (i.e. horses and high-rises, which also represent the nation's past and its future) and immediately announcing the film as Uruguayan. Additional shots of prominent recent architectural achievements such as the Casino Carrasco and the Parque Hotel helped construct an image of national advancement and of Uruguay as a modern nation, an image elites (and others) were keen to project both at home and abroad. The use of local slang throughout the film, and early shots of the hero drinking yerba mate, reflect a modified elite view in which certain aspects of local popular culture could be embraced (in a sanitized form) by elites seeking nationalist credentials. Situating itself at the center of the nationalist project is yet another way in which Del Pingo played to the narcissism and paternalism of the elite outlook.

\section{CONCLUSION}

This history rests in a nexus of women's history, film history, and the history of state formation in Latin America, and thus contributes to our knowledge and understanding of all three of these trajectories. This material also allows us to better define the ways in which global phenomena were localized in particular Latin American settings and shaped by local context. In the Uruguayan case, cinema and movie going attached to local forces and patterns, and was thus very much a product and reflection of the Batllista era. That elite women would assume such a leading role in early cinema may seem surprising at first, but within the context of local conditions and circumstances, the prominence of beneficent cinema in Uruguay makes sense. One could even call this category of filmmaking "cine batllista," for even though it reflects none of the ideologies or realities of Batllismo directly, it clearly mirrors some of its consequences and the specific way that Batllismo shaped elite notions of crisis and degeneration in the 1920s. In other words, it speaks to attempts by the Uruguayan elite to preserve its place in the social fabric, at a time when welfare state formation was rendering the position of elite women increasingly vague and tenuous. Certainly far more research into this subject is needed, and the present study is merely an initial explo- 
ration based on limited source material. Further research on silent cinema elsewhere in Latin America will undoubtedly shed important contextual light on the Uruguayan case as well. Among other things, it will hopefully reveal whether the important role Uruguayan women played in both film making and the promotion of movie-going in the early years was replicated in other parts of Latin America.

I suggest that Del Pingo's message fit in with the Bonne Garde's project in important ways. This film is about the struggles and the identity crisis of the elite in a period of growing economic crisis and rising nationalism, and in the context of the Batllista welfare state. In order to properly understand this film in this light, one must read class and gender as an intersecting whole, and as two components of the same structure of power and hierarchy. In simple terms, the state was usurping many of the paternalistic roles of the elite, using elite women as temporary surrogates facilitating their very disempowerment. ${ }^{35}$ By the later 1920 s it had become clear what was at stake: private fundraising and a defense of traditional notions of paternalism and noblesse oblige were imperative. Thus the moral crisis of the elite depicted on screen in Del Pingo was also an immediate social and political crisis for the damas of the Bonne Garde and other ladies' committees. The film, through its hoped-for proceeds and prestige, and through its message of elite regeneration, was supposed to engender a similar salvation to that realized on screen.

University of Louisville

CHRISTINE EHRICK

Louisville, Kentucky

${ }^{35}$ Alison Parker discusses a similar pattern in the United States, where a 'male-dominated' state regulatory apparatus began to encroach on the traditionally female world of social assistance in the early twentieth century. See Alison M. Parker, Purifying America: Women, Cultural Reform, and Pro-Censorship Activism, 1873-1933 (Chicago: University of Illinois Press, 1997), p. 10. 